\title{
The History of the APS Topical Group on Shock Compression of Condensed Matter
}

\author{
J.W. Forbes
}

This article was submitted to $12^{\text {th }}$ Biennial International Conference on the American Physical Society Topical Group on Shock Compressed of Condensed Matter, Atlanta, GA., June 24-29, 2001

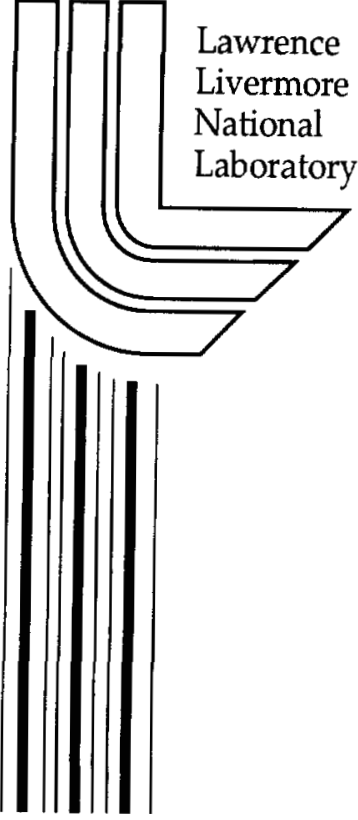

\section{October 19, 2001}




\section{DISCLAIMER}

This document was prepared as an account of work sponsored by an agency of the United States Government. Neither the United States Government nor the University of California nor any of their employees, makes any warranty, express or implied, or assumes any legal liability or responsibility for the accuracy, completeness, or usefulness of any information, apparatus, product, or process disclosed, or represents that its use would not infringe privately owned rights. Reference herein to any specific commercial product, process, or service by trade name, trademark, manufacturer, or otherwise, does not necessarily constitute or imply its endorsement, recommendation, or favoring by the United States Government or the University of California. The views and opinions of authors expressed herein do not necessarily state or reflect those of the United States Government or the University of California, and shall not be used for advertising or product endorsement purposes.

This is a preprint of a paper intended for publication in a journal or proceedings. Since changes may be made before publication, this preprint is made available with the understanding that it will not be cited or reproduced without the permission of the author.

This work was performed under the auspices of the United States Department of Energy by the University of California, Lawrence Livermore National Laboratory under contract No. W-7405-Eng-48.

This report has been reproduced directly from the best available copy.

Available electronically at http://www.doc.gov/bridge

Available for a processing fee to U.S. Department of Energy

And its contractors in paper from

U.S. Department of Energy

Office of Scientific and Technical Information

P.O. Box 62

Oak Ridge, TN 37831-0062

Telephone: (865) 576-8401

Facsimile: (865) 576-5728

E-mail: reports@adonis.osti.gov

Available for the sale to the public from

U.S. Department of Commerce

National Technical Information Service

5285 Port Royal Road

Springfield, VA 22161

Telephone: (800) 553-6847

Facsimile: (703) 605-6900

E-mail: orders@ntis.fedworld.gov

Online ordering: http://www.ntis.gov/ordering.htm

OR

Lawrence Livermore National Laboratory

Technical Information Department's Digital Library

http://www.llnl.gov/tid/Library.html 


\title{
THE HISTORY OF THE APS TOPICAL GROUP ON SHOCK COMPRESSION OF CONDENSED MATTER
}

\author{
Jerry W. Forbes \\ Lawrence Livermore National Laboratory, P.O. Box 808, L-282, Livermore, CA 94551
}

\begin{abstract}
In order to provide broader scientific recognition and to advance the science of shock compressed condensed matter, a group of American Physical Society (APS) members worked within the Society to make this field an active part of the APS. Individual papers were presented at APS meetings starting in the 1940's and shock wave sessions were organized starting with the 1967 Pasadena meeting. Shock wave topical conferences began in 1979 in Pullman, WA. Signatures were obtained on a petition in 1984 from a balanced cross-section of the shock wave community to form an APS Topical Group (TG). The APS Council officially accepted the formation of the Shock Compression of Condensed Matter (SCCM) TG at its October 1984 meeting. This action firmly aligned the shock wave field with a major physical science organization. Most early topical conferences were sanctioned by the APS while those held after 1992 were official APS meetings. The topical group organizes a shock wave topical conference in odd numbered years while participating in shock wave/high pressure sessions at APS general meetings in even numbered years.
\end{abstract}

\section{INTRODUCTION}

Shock wave research has had a long tradition of involvement in the APS going back to individual papers at APS meetings in the 1940's. Over the years, increasing number of papers have been presented at APS meetings, In the 1980's, many scientists worked diligently within the APS to demonstrate that the field of shock compression of condensed matter met APS criteria for the formation of a topical group. The topical group provides good visibility to this field within the broader framework of the physics community.

The motivation of the shock compression scientists was inspired by the need to broaden the development of the science. The commitment to this science, both within and outside academia was extraordinary and a nationwide trend to understand the science of shock compression of condensed matter was joined by many researchers in related fields of mechanics, materials science, chemistry, mathematics, and computer science. The research efforts of individual APS members were made possible by the support of government research sponsors, universities, and private corporations.
As with many areas of physics, government sponsorship of this field was motivated by the relevance to defense applications. Subsequently, this field has developed into one of scientific interest in its own right.

Shock compression research has found application in many areas of physics, chemistry, material science, geophysics, fluid dynamics, and solid mechanics. The field gained acceptance in highpressure science in part due to a controversy between static high pressure and shock wave compression results on the phase transition in iron[1,2].

\section{EARLY PAPERS AT APS MEETINGS}

Papers on shock waves in condensed matter started showing up at APS meetings in 1947. Twenty-one shock wave papers were presented at the May 1947 meeting[3] in Washington, D.C. This was the first APS meeting with a significant number of shock wave papers. A majority of these papers were on the properties of shock waves in water and were presented mostly by scientists from the Underwater Explosives Research Laboratory and the Naval Ordnance Laboratory (NOL). According 
to G. Hartman[3] from NOL, these papers were motivated by fundamental questions that came from underwater ordnance research in World War II. It is of interest to note that Hans Bethe from Cornell gave a theoretical talk on shock wave conditions, as did J. G. Kirkwood and S. Brinkley, also from Comell. In addition, S. J. Jacobs of NOL outlined the importance of making temperature measurements in detonating explosives: a problem of continuing contemporary interest.

There have been numerous APS meetings since 1947 where just two or three shock wave papers were submitted. The meetings where six or more papers were given are listed in Table 1 . Most papers on shock waves in the early days were given in the Fluid Dynamics Division's sessions.

A representative list of scientists from major shock wave laboratories that gave APS papers from 1948 through 1960 provides a glimpse at the early work in the field. Representative papers are from Los Alamos Scientific Laboratories[4-10], Lawrence Livermore Laboratory[11], Sandia National Laboratory[12-15], Naval Ordnance Laboratory[3,16-19], Naval Weapons Test Station [3,20-23], Army Research Laboratory[3,24-25], and Stanford Research Institute[26-31].

Special symposia on shock waves in liquids and solids given at Division of Fluid Dynamics meetings provided an additional view of the early research. A symposium on Explosion Phenomena occurred at the June 1952 meeting[32] in Salt Lake City which featured J. O. Hirschfelder from the University of Wisconsin, M. A. Cook from U. of Utah, J. S. Rinehart from Naval Ordnance Test Station, and E. F. Cox from Sandia Corporation. The first shock wave symposium on non-reacting condensed matter occurred at the January 1954 New York APS meeting[33]. This symposium featured J. M. Walsh, F. J. Willig, and T. P. Cotter from Los Alamos, and D. F. Hornig from Brown University.

\section{IRON COMPRESSIBLITY CONTROVERSY}

Security restrictions[34] kept Los Alamos from publishing papers on shock waves until 1952[4,5]. An historically important APS paper[35] was given at the January 1954 New York meeting by J. M. Walsh on the propagation of compressive shock waves with pressures near $40 \mathrm{GPa}$ in Armco iron. This paper reported disagreements with lower pressure data such as Bridgman's static compressibility, and shock data (unpublished at the time) by Goranson et al.[36] and Minshall[37]. The disagreements between data sets led to the research described in the now famous 1956 journal article by Bancroft, Peterson and Minshall[38]. It is of historical interest to note that many journal papers [e. g. 36-37, 39-42] were published on shock waves in condensed matter prior to this paper. This earlier work provided a precedent for this kind of research.

Static high-pressure pioneer P. W. Bridgman disagreed with the iron transition pressure found for the shock wave research[1]. Bridgman subsequently found that he was using an incorrect high-pressure scale[1]. The shock wave results were then corroborated by improved static work[1]. This finding lead to the establishment of an accurate high-pressure scale based on shock wave phase transition data.

Bridgman also stated that the phase transition processes in iron could not occur fast enough to be observed in shock waves. Effort continues to date toward understanding the shock wave deformation processes which allow for such fast transitions.

The intense controversy created by the Bancroft et al.[38] paper exposed shock compression physics to the broader physics community and lead to its acceptance as a branch of science. A new field of science was born: very high pressure physics.

\section{SHOCK COMPRESSION SESSIONS AT APS MEETINGS}

To understand the history of the topical group requires knowing how involvement in APS meetings progressed. The three sub-sections of Table 1 illustrate three major trends in APS meeting participation (excluding TG conferences). The first set gives early informally organized meetings prior to 1967 . These meetings set precedence for APS involvement and included seminal scientific events for the field. The second set gives meetings prior to the topical group. These were organized principally by Sandia National Laboratory scientists. The third set gives topical group organized meetings. 
TABLE 1. Summary of Shock Wave Physics Programs at APS Meetings other than Shock Compression Topical Conferences with six or more papers.

\begin{tabular}{|c|c|c|c|c|}
\hline Meeting Date & Locations & Contributed & Invited & BAPS reference* \\
\hline \multicolumn{5}{|l|}{ EARLY PAPERS } \\
\hline May 1947 & Washington & 21 & - & $\begin{array}{l}\text { Phys. Rev., 72(2), } \\
\text { pp. 115-180, July } 1947\end{array}$ \\
\hline June 1952 & Salt Lake City & 9 & - & $\begin{array}{l}\text { Phys. Rev., 87(5), } \\
\text { pp. } 909-913, \text { Sept. } 1952\end{array}$ \\
\hline Dec. 1960 & Berkeley & 9 & - & II, 5, No. 7, p. $306,510-511$ \\
\hline June 1961 & Mexico City & 6 & - & II, 6, No. 4 , pp. $348-349$ \\
\hline \multicolumn{5}{|c|}{ MULTHLLABORATORY ORGANIZED SESSIONS } \\
\hline Dec. 1967 & Pasadena & 16 & - & II, 12, No. 8, pp. $1127-1130$ \\
\hline Dec. 1968 & San Diego & 31 & - & II, 13, No. 12, pp. 1660,1676 \\
\hline Dec. 1969 & UCLA & 32 & - & $\begin{array}{l}11,14, \text { No. } 12, \text { pp. } 1155,1163 \text {, } \\
1169\end{array}$ \\
\hline Dec. 1970 & Stanford & 43 & - & $\begin{array}{l}\text { II, 15, No. } 12, \text { pp. } 1592,1605 \text {, } \\
1616,1624\end{array}$ \\
\hline $\begin{array}{l}\text { Nov. } 1972 \\
\text { (Fluid Dynamics meeting) }\end{array}$ & Boulder & 41 & 1 & $\begin{array}{l}\text { II, 17, No. 11, pp. 1083-1084, } \\
\text { 1092-1093, 1099-1100, 1105- } \\
1106,1112-1113\end{array}$ \\
\hline Dec. 1973 & Berkeley & 14 & - & $\begin{array}{l}\text { II, 18, No. 12, pp. 1592-1594, } \\
\text { 1599-1600 }\end{array}$ \\
\hline Jan. 1975 & Anaheim & 45 & 3 & $\begin{array}{l}\text { II, 20, No. 1, pp. } 19-21,25,48-50 \text {, } \\
61-62\end{array}$ \\
\hline Dec. 1975 & Pasadena & 54 & 2 & $\begin{array}{l}\text { II, 20, No. 12, pp. 1489-1491, } \\
1497-1498,1506-1508, \\
1513-151\end{array}$ \\
\hline Dec. 1976 & Stanford & 40 & 3 & $\begin{array}{l}\text { II, 21, No. 11, pp. 1286-1287, } \\
1291-1292.1298-1299\end{array}$ \\
\hline Jan. 1978 & San Francisco & 59 & 2 & $\begin{array}{l}\text { II, } 23, \text { No. 1, pp. 35-37, 53-54, } \\
69-71,95-96,104-106\end{array}$ \\
\hline \multicolumn{5}{|c|}{ TOPICAL GROUP ORGANIZED SESSIONS } \\
\hline April 1980 & Washington & 36 & 2 & $\begin{array}{l}\text { II, } 25 \text {, No. } 4 \text {, pp. } 495-497 \text {, } \\
513-516\end{array}$ \\
\hline April 1982 & Washington & 34 & 4 & $\begin{array}{l}\text { II, } 27, \text { No. } 4 \text {, pp. } 454-455 \text {, } \\
465-466,485-487,507-508\end{array}$ \\
\hline April 1984 & Washington & 31 & 3 & $\begin{array}{l}\text { II, } 29 \text {, No. } 4 \text {, pp. } 724-725 \text {, } \\
740-742,749-750,758-760\end{array}$ \\
\hline April 1986 & Washington & 25 & 3 & $\begin{array}{l}\text { II, 31, No. } 4, \text { pp. } 803-804, \\
823-824,837-838\end{array}$ \\
\hline Mar. 1988 & New Orleans & 41 & 2 & $\begin{array}{l}\text { II, 33, No. 3, pp. 536-537, } \\
581-582,630-632,710-711\end{array}$ \\
\hline Mar. 1990 & Anaheim & 21 & 1 & $\begin{array}{l}\text { II, 35, No. 3, pp. 697-699, } \\
806-808\end{array}$ \\
\hline Mar. 1992 & Indianapolis & DMP & 1 & II, 37, No. 1, pp. 361-362 \\
\hline Mar. 1994 & Pittsburgh & DMP & - & II, $\mathbf{3 9}$, No. 1 \\
\hline Mar. 1996 & St. Louis & DMP & 1 & II, 41, No.1 \\
\hline Mar. 1998 & Los Angeles & DMP & - & II, 43, No. 1 \\
\hline Mar. 2000 & Minneapolis & DMP & 2 & II, 45, No. 1 \\
\hline
\end{tabular}

*Proceedings of APS were published in Physical Review until 1956 then the APS Bulletin (BAPS) became an archival publication on its own 
The early APS meetings with shock compression sessions were in the Western United States. Note that the shock wave condensed matter community had been aligned with the Division of Fluid Dynamics for many of the early years. However, this Division's main interest was in gas hydrodynamics. At some point in the 1960's, shock wave scientists, working on liquids and solids, decided to align themselves with an established condensed matter group. This led to the formation of an informal group inside APS working on shock waves in condensed matter.

The principal APS contact during the 1960's was Professor Ward Whaling, West Coast Secretary, who was unusually cooperative in helping shock compression scientists present papers and organize sessions at the APS' winter meetings. Bob Graham recalls Ward's declaration that "Physics is whatever an APS member thinks it is." The broad and flexible nature of the APS has provided the seedbed and nurture for shock wave compression studies.

The first formally organized session was at the Dec. 1967 Winter APS meeting in Pasadena. This meeting provided the momentum to eventually develop into a more formal group. Glen Seay of Sandia had approached Ward Whaling about organizing shock wave sessions. Whaling was aware of prior participation by shock wave scientists in APS meetings and agreed to allow organized shock wave sessions to be a part of the general meeting. Glen Seay, Orval Jones, and Lee Davison of Sandia solicited colleague's participation over the telephone. The resulting shock wave sessions attracted large enthusiastic audiences spilling out into the hall. Ward Whaling was impressed, because most other sessions were lightly attended. It is of interest to note that an early social event for the shock wave community occurred at this meeting. Tom Ahrens hosted a dinner for the shock wave participants at his home.

Starting in 1980 , sessions were organized at the APS Spring meeting in Washington, D.C. on alternate years (see Table 1) to allow East Coast shock wave scientists to fully participate. Robert Graham and Jerry Forbes organized the shock wave sessions for these East Coast meetings.

Topical conferences began in 1979 in Pullman, WA where George Duvall and Dennis Hayes were co-chairs. The topical conference in Atlanta, GA in 2001 was our twelfth. Topical conferences prior to 1992 were just meetings sanctioned by APS. After becoming an official APS unit in 1992, topical conferences became official APS meetings. A list of topical conferences is given in Table 2 .

To provide increased interactions with the established APS Condensed Matter Division, a policy was set at the 1987 TG business meeting to organize sessions at the APS general March meeting in years when the topical conference is not held. The first joint APS March meeting with organized shock wave sessions was at the 1988 New Orleans meeting. At the March 1992 meeting, it was decided that it would be beneficial to hold off-year meetings with the static high pressure group in the Division of Material Physics (DMP). This useful alliance with DMP continues to date.

Publications of APS topical conference proceedings started with the 1981 Menlo Park meeting. These publications provide a solid foundation for the development of the science. They require substantial effort from a number of people. Table 3 lists the publication chairs that provided the leadership for this accomplishment.

Numerous contributors have helped the topical group meetings become successful. William Deal and Alita Roach of Los Alamos National Laboratory deserve special recognition for their outstanding organizational assistance at numerous topical group conferences.

\section{THE FORMATION OF THE APS TOPICAL GROUP}

In the 1980's the APS, recognizing that a number of focus groups were active participants at meetings, decided to do an experiment and form topical groups. This experiment was to see if APS could serve these focus groups better. At this time, the topical groups were not officially recognized in the APS bylaws as official units, and lacked certain privileges that Divisions and Regional groups had.

William Havens, APS executive secretary, contacted Robert Graham to see if he would be willing to organize a topical group. In 1984, after consulting with a number of people, Graham 
TABLE 2. Shock Compression of Condensed Matter Topical Conferences.

\begin{tabular}{|c|c|c|c|}
\hline Chairs/Co-chairs & Conference Date & BAPS reference & Location \\
\hline $\begin{array}{l}\text { George E. Duvall, and } \\
\text { Dennis B. Hayes }\end{array}$ & June 1979 & II, 24, No. 4, p. 709 & Pullman, WA \\
\hline $\begin{array}{l}\text { William J. Nellis, and } \\
\text { Lynn Seaman }\end{array}$ & June 1981 & II, 26, No.4, p. 647 & Menlo Park, CA \\
\hline $\begin{array}{l}\text { James R. Asay, and } \\
\text { Galen K. Straub }\end{array}$ & July 1983 & None & Santa Fe, NM \\
\hline Yogendra M. Gupta & July 1985 & II, 30, No. 8, p. 1289. & Spokane, WA \\
\hline Neil C. Holmes & June 1987 & II, 30, No. 6, p. 1355 & Monterey, CA \\
\hline James $\mathbf{N}$. Johnson & July/August 1989 & II, 34, No. 7, p. 1695 & Albuquerque, NM \\
\hline $\begin{array}{l}\text { Richard D. Dick, and } \\
\text { Douglas G. Tasker }\end{array}$ & June 1991 & II, 36, No. 6, p. 1813 & Williamsburg, VA \\
\hline $\begin{array}{l}\text { John W. Shaner, } \\
\text { George A. Samara, } \\
\text { and Marvin Ross }\end{array}$ & June-July 1993* & II, 38, No. 6, p. 1467 & Colorado Springs, CO \\
\hline William Tao & August 1995 & II, 40, No. 8,p. 1375 & Seattle, WA \\
\hline Dattatraya Dandekar & July-August 1997 & II, 42, No. 5, p. 1491 & Amherst, MA \\
\hline $\begin{array}{l}\text { Lalit C. Chhabildas } \\
\text { and Robert. S. Hixson }\end{array}$ & June-July 1999 & II, 44, No. 2, p. 3 & Snowbird, UT \\
\hline $\begin{array}{l}\text { Naresh N. Thadhani } \\
\text { and Yasuyuki Horie }\end{array}$ & June 2001 & II, 46, No. 4, p. 1 & Atlanta, GA \\
\hline
\end{tabular}

TABLE 3. Shock Compression Topical Conference's Publication Chairs.

L. Seaman, W. J. Nellis, and

$\begin{array}{ll}\text { R. A. Graham } & 1981 \\ \text { Galen Straub and James Asay } & 1983 \\ \text { Yogendra Gupta } & 1985 \\ \text { Stephen C. Schmidt } & 1987-1999 \\ \text { Michael D. Furnish } & 1999-\text { present }\end{array}$

circulated a petition to form the APS topical group. He obtained signatures from a balanced crosssection of the community (10 fellows, 27 APS members). The signers of this petition are listed in Table 4.

Bill Havens informed Bob Graham by letter dated November 28, 1984 that the APS Council had officially accepted the formation of the topical group at its October 28, 1984 meeting. The first election occurred July 23, 1985 at the Spokane topical conference where Robert Graham was elected chairman, William Nellis vice-chairman, and Jerry Forbes secretary/treasurer. A list of the chairs and secretary/treasurers of the $T G$ are given in Table 5 .

The first topical group chair, Bob Graham, decided to separate the duties of the meeting chair from the task of being the principal editor of the proceedings. Steve Schmidt readily volunteered to be the first publications chair, appointed by the TG chair, and served in that role until 1999. A second new policy initiated by Graham was the establishment of an award for shock compression science. The establishment of this APS award is discussed in the next section.

In the 1990-1992 period, APS wrote a new constitution and bylaws recognizing the topical groups as official units of APS. This meant that the topical groups bylaws, drafted in 1989 by James Asay, had to be brought into compliance with APS'. APS bylaws now required that all units had to have the same structure and tenure of officers. Jerry Forbes and E. Ray Lemar accomplished this task. Another change was that topical groups could now elect Fellows every year 
TABLE 4. Petition signers for the formation of the Topical Group.

\begin{tabular}{ccc}
\hline Thomas J. Ahrens & William E. Deal, Jr. & Bruno Morosin \\
Berni Alder & George E. Duvall & W. J. Nellis \\
Salvo E. Arione & Robert S. Flock & Baldev Paytal \\
James Russell Asay & Jerry W. Forbes & M. Ross \\
Paul M. Bellamy & G. Richard Fowles & Lynn Seaman \\
Michael Dean Bjorkman & H. C. Graboske & John Wesley Shaner \\
Marx Brook & R. A. Graham & Donald H. Tsai \\
Anthony J. Campillo & Yogendra M. Gupta & Douglas Venable \\
Donald Robert Curran & Paul Harris & Jerry Wackerle \\
Dattatraya P. Dandekar & W. G. Hoover & Duane C. Wallace \\
Lee W. Davison & Yasuyuki Horie & Frederick L. Yarger \\
Paul S. De Carli & J. N. Johnson & Gerold Yonas \\
& A. M. Karo & \\
\hline
\end{tabular}

TABLE 5. Officers of the Topical Group.

\begin{tabular}{ll}
\hline Chair & Term \\
Robert A. Graham & $1985-1986$ \\
William J. Nellis & 1987 \\
Galen K. Straub & 1988 \\
Thomas J. Ahrens & 1989 \\
James R. Asay & 1990 \\
John W. Shaner & 1991 \\
Stephen C. Schmidt & 1992 \\
Jerry W. Forbes & 1993 \\
Dennis E. Grady & 1994 \\
Yogendra M. Gupta & 1995 \\
Lalit C. Chhabildas & 1996 \\
James N. Johnson & 1997 \\
Donald R. Curran & 1998 \\
Neil C. Holmes & 1999 \\
Dattatraya P. Dandekar & 2000 \\
Stephen A. Sheffield & 2001 \\
& \\
Secretary/Treasurer & \\
Jerry W. Forbes & $1985-1991$ \\
E. Ray Lemar & $1992-1997$ \\
J. Michael Boteler & $1998-$ present \\
\hline
\end{tabular}

as a small percentage of its membership (specified in the bylaws), and if the topical group is large enough it can elect an APS councilor. For us, a small topical group, the new APS bylaws allow the nomination of one or two fellows per year but not an APS councilor.

Prior to the topical group becoming an official entity of APS, we were asked to submit nominations to the APS Fellow committee, which would give us consideration for Fellow nominations without going through a Division. APS did this in order to serve their smaller units better. Our informal group was successful in nominating Dennis Grady for a fellow in 1985 using this route. The list of fellows sponsored by the topical group after its formation is given in Table 6.

TABLE 6. Fellows sponsored by the Topical Group.

\begin{tabular}{ll}
\hline Yogendra M. Gupta & 1991 \\
James Asay and Jerry Forbes & 1992 \\
Marvin Ross & 1994 \\
Donald R. Curran & 1995 \\
Lynn M. Barker and & \\
$\quad$ James N. Johnson & 1996 \\
Richard G. Fowles and & 1997 \\
$\quad$ Yasuyuki Horie & 1998 \\
Neil C. Holmes and Andrew Ng & \\
\hline
\end{tabular}

\section{APS SHOCK COMPRESSION SCIENCE AWARD}

The first attempt by Robert Graham to get Council to approve a shock compression APS science award was unsuccessful because some Council members thought that the shock compression field was too narrow to warrant such a long-standing award. Many members of the shock wave community, along with some members of APS' Division of Condensed Matter Physics, 
disagreed with this decision. William Nellis, Robert Graham and Neil Ashcroft got the APS Council to reconsider their position. The 1987 topical group chair, William Nellis, presented a revised award proposal to the January 26, 1987 Council meeting. In the meantime, the APS Council had received a number of letters by prominent scientists such as: Neil Ashcroft, William F. Brinkman, M. Brian Maple, Theordore H. Geballe, A. Jayaraman, Cecil E. Land, Arthur L. Ruoff, Bruno Morosin, William Band, and V. I. Goldanskii, in favor of the formation of this award. The APS Council was satisfied with the additional information and approved the award at their January 1987 meeting.

\section{AWARD PURPOSE}

The friends of the topical group endowed this APS award in 1987 to recognize contributions to the understanding of condensed matter and non-linear physics through shock compression. All members of the scientific community are eligible for nomination. The award is presented at the biennial topical group conference. The first award was given jointly to Robert G. McQueen, Melvin H. Rice, and John M. Walsh, all of Los Alamos, recognizing their contributions in forming a new very high pressure field. The award winners to date are given in Table 7.

Each award winner is presented a cash award and an award medallion, which is an explosively fabricated line graph of the iron phase transition. The history of the medallion is given in Appendix A.

TABLE 7. APS Shock Science Award Winners.

$\begin{array}{ll}\begin{array}{l}\text { Robert G. McQueen, } \\ \text { Melvin H. Rice, and }\end{array} \\ \text { John M. Walsh } & 1987 \\ \text { George E. Duvall } & 1989 \\ \text { Lev V. Al'tshuler } & 1991 \\ \text { Robert A. Graham } & 1993 \\ \text { Thomas J. Ahrens } & 1995 \\ \text { Arthur C. Mitchell and } & \\ \text { William J. Nellis } & 1997 \\ \text { Lynn M. Barker } & 1999 \\ \text { Yogendra M. Gupta } & 2001\end{array}$

\section{FINAL COMMENTS}

Our topical group benefits from the broader visibility provided by the APS and, in turn, APS benefits from the association with our unique approach to very high pressure science.

A group of scientists worked hard to demonstrate to the APS that we met the criteria to form a topical group. This resulted in gaining approval for the topical group and for the APS shock science award. It is important to maintain our stature as a science-based group in the APS. Therefore, our meetings need to maintain focus on the advancement of shock compression science while including related technologies.

\section{ACKNOWLEDGEMENTS}

The author gratefully acknowledges input from James Asay, J. Michael Boteler, William Deal, Robert Graham, Yogendra Gupta, E. Ray Lemar, William Nellis and other individuals. Reference notes for this article came from Robert Graham, BAPS, shockwave literature and my topical group secretary/treasurer files starting in 1984. Cynthia Forbes and Linda Null reviewed this paper for clarity of presentation. Every persons' involvement could not be noted in this paper but an effort was made to recognize significant contributions where known or documented. The author also wishes to recognize Professor George E. Duvall who taught him that people can have different approaches to problem solving and that all can contribute to the understanding and advancement of science if they have a passion to do so. This work was performed under the auspices of the U.S. Department of Energy by the University of California, Lawrence Livermore National Laboratory under Contract No.W-7405-Eng-48.

\section{REFERENCES}

1. Graham, R. A, "Bridgman's Concern", in HighPressure Science and Technology-1993, AIP Conference Proceedings 309, 1994, pp. 3-12.

2. Bridgman, P. W., "High Pressure Polymorphism of Iron," J. Appl. Phys. 27, p. 659 (1956).

3. Washington D.C. May 1947 Meeting, Proc. Phys. Soc., Phys. Rev. 72(2), pp.151-180 (July 1947).

4. Lucy, F. A. and. Shreffler, R. G, "Fast Jets from Collapsing Cylinders," Proc. Phys. Soc., Series $I I, 88(1)$, p. 161 (Oct. 1952). 
5. Deal, W. E and Shreffler, R G., "Free Surface Properties of Explosive-Driven Metal Plates," Proc. Phys. Soc., Phys. Rev. 87(5), p. 910 (Sept. 1952).

6. Minshall, S., "Separation of a Shock Wave into Elastic and Plastic Waves and Measurement of the Pressure of the Elastic Wave," Proc. Phys. Soc., Phys. Rev. 91(4), p. 1030 (Aug. 1953).

7. Christian, R. H. and Walsh, J.M., "An Experimental Method to Determine Equation of State Data for Solids by Shock Wave Measurements," Proc. Phys. Soc., Phys. Rev. 91(4), p. 1030 (Aug. 1953).

8. Rice, N. H. and Walsh, J. M., "Properties of Liquids in Strong Shock Waves," Proc. Phys. Soc. II, 1(7), p. 361 (Nov. 1956).

9. Wackerle, Jerry, "Shock-Wave Compression of Quartz," Proc. Phys. Soc, Series II, 5(7), p. 510, (Dec. 1960).

10. McQueen, R. G. and Marsh, S. P., "Ultimate Yield Strength of Copper," Proc. Phys. Soc, Series II, 5(7), p. 506 (Dec. 1960).

11. Grover, R. Christian, R. H., and Alder, B. J., "Shock-Induced Phase Transitions in Nonmetallic Elements," Proc. Phys. Soc, Series II, 3(3), p. 230 (May 1958).

12. Neilson, F. W., "Effects of Strong Shocks in Ferroelectric Materials," Proc. Phys. Soc, Series II, 2(6), p. 302 (Sept. 1957).

13. Anderson, G. W. and Neilson, F. W., "Effects of Strong Shocks in Ferromagnetic Materials," Proc. Phys. Soc, Series II, 2(6), p. 302 (Sept. 1957).

14. Graham, R. A., "Piezoelectric Behavior of Impacted Quartz," Proc. Phys. Soc, Series II, 5(7), p. 511 (Dec. 1960).

15. Brooks, W. P. and Neilson, F. W." "Shock-Induced Luminescence of Quartz," Proc. Phys. Soc, Series II, 5(7), p. 511 (Dec. 1960).

16. Savitt, J. and Stresau, R. H F., "Electrical Properties of Detonation Shocks," Proc. Phys. Soc., Series $I I, 83(1)$, p. 200 (July 1951).

17. Starr, L. and Savitt, J., "Spalling Produced by Detonation of Explosives in Very Heavy Walled Metal Tubes," Proc. Phys. Soc., Series II, 86(4), p. 600 (May 1952).

18. Solow, M., Coleburn, N., Wiley, R., Jacobs, S. J., and Drimmer, B., "Surface Reflectivity of Aluminum Subjected to Shocks," Proc. Phys. Soc, Series II, 4(3), p. 175 (March 1959).

19. Coleburn, N. L., Solow, M., and Wiley, R. C., "Vacancies and Shocks in Metals," Proc. Phys. Soc, Series II, 5(3), p. 154 (March 1960).

20. Rinehart, J. S., "A Type of Fracture Produced in Steel by Explosive Attack," Proc. Phys. Soc., Phys. Rev., 81(4), p. 659 (Feb. 1951).
21. Allen, W. A, and. McCary, C. L, "Transient Waves through Steel Produced by Impulsive Loading," Proc. Phys. Soc., Phys. Rev. 85(4), p. 769 (Feb. 1952).

22. Backman, M., "Elastic and Plastic Behavior in Simple Target-Projectile Systems," Proc. Phys. Soc, Series II, 1(8), p. 377 (Dec. 1956).

23. LaRocca, E. W. and Burkardt, L A., "Effect of Impulsive Loads on the Structure of Cobalt," Proc. Phys.Soc, Series II, 2(5), p. 263 (June 1957).

24. Dewey, J. N., Breidenbach, Jr., H. I., and Gehring, Jr., J. W., "Determination of Detonation Pressures from Flash Radiographs," Proc. Phys. Soc., Phys. Rev. 87(5), p. 909 (June 1952).

25. Zernow, L., "Flash Radiographic Studies of High Velocity Metallic Jets," Proc. Phys. Soc, Series II, Phys. Rev. 92(2), p. 532 (Oct. 1953).

26. Katz, S., "Velocity of Explosively-Induced Shock in Steel," Proc. Phys. Soc, Series II, 29(8), p. 8 (Dec. 1954).

27. Duvall, G. E, "Linearized Flow Theory and Shock Waves in Metals," Proc. Phys. Soc., Phys. Rev. 100(3), p. 967 (Nov. 1955).

28. Erkman, J. O., "Free Surface Motion Due to Obliquely Incident Shock Waves," Proc. of Phys. Soc., Phys.Rev. 100(6), p. 1801 (Dec. 1955).

29. Kelley, John J. and DeCarli, Paul, "Shock Twinning of Molybdenum," Proc. Phys. Soc, Series II, 2(8), p. 369 (Dec. 1957).

30. Fowles, G. Richard, "Shock Wave Compression of Hardened and Annealed 2024 Aluminum," Proc. Phys. Soc, Series II, 5(7), p. 510 (Dec 1960).

31. Curran, Donald R, "On the Possibility of Detecting Shock Induced Second Order Phase Transitions in Solids," Proc. Phys. Soc, Series II, 5(7), p. 510 (Dec. 1960).

32. Salt Lake City June 1952 Meeting, Proc. Phys. Soc., Phys. Rev. 87(5), p. 909 (Sept. 1952).

33. New York January Meeting, Bull. Am. Phys. Soc. 29(1), p. 28 (1954).

34. Taylor, J. W., "Thunder in the Mountains," in Shock Waves in Condensed Matter-1983, Elsevier Science Pub., B. V., 1984, pp. 3-15.

35. Walsh, J. M., "Metal Equation of State from ShockWave Studies," Bull. Am Phys. Soc. 29(1), p. 28 (1954).

36. Goranson, R. W., Bancroft, D., Burton, B. L, Blechar, T., Houston, E. E, Gittings, E. F., and Landeen, S. A, "Dynamic Determination of the Compressibility of Metals," J. Appl. Phys. 26, pp. 1472-1479 (1955)

37. Minshall, F. S., "Properties of Elastic and Plastic Waves Determined by Pin contactors and Crystals," J. Appl. Phys. 26, pp. 463-469 (1955) 
38. Bancroft, D., Peterson, E. L., and Minshall, S., "Polymorphism of Iron at High Pressure," J. Appl. Phys. 27(3), pp. 291-298 (1956).

39. McMillen, J. H., "Shock Wave Pressures in Water Produced by Impact of Small Spheres," Phys. Rev. 68(9\&10), pp. 198-209 (1945).

40. Brinkley, Jr., S. R., and Kirkwood, J. G., "Theory of the Propagation of Shock Waves from Infinite Cylinders of Explosives," Phy. Rev. 72(11), pp. 1109-1113 (1947).

41. Pack, D. C., Evans, W. M., and James, H. J., "The Propagation of Shock Waves in Steel and Lead," in Proc. Physical Society 60(Part 1, No.337), pp. 1-8, (1948).

42. Mallory, H. Dean, "Propagation of Shock Waves in Aluminum," J. Appl. Phys. 26, pp. $555-559(1955)$

\section{APPENDIX A. AWARD MEDALLION}

The first set of medallions were explosively fabricated in 1987 from a porous copper compact by the Center for Explosive Technology Research (CETR) of New Mexico Tech at Socorro, New Mexico[A1]. It was furnished as a complimentary contribution to the Group from CETR through the courtesy of the Director at that time, Dr. Per Anders Persson. Process development and fabrication was under the direction of Dr. Naresh Thadhani.

A special raised pattern is explosively imprinted on the face of the medallion as shown in Fig. A-1. The pattern is a representation of the pressurevolume relation of shock-compressed iron, emphasizing the 13-GPa structural phase transition. The Hugoniot, or loading portion of the curve, represents the original data obtained by Stanley Minshall and his coworkers at Los Alamos. The release wave portion of the pattern represents the

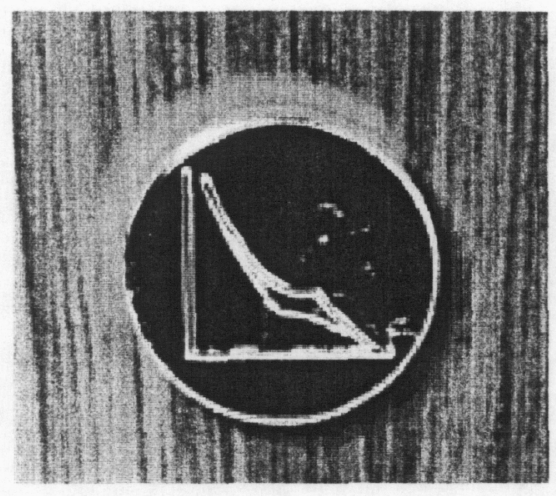

FIGURE A-1. The Award Medallion.

data obtained by Lynn Barker of Sandia with VISAR instrumentation.

The discovery of the 13-GPa transition was one of the first major achievements of shock-compression science. The transition was first discovered by the shock-compression technique and contradicted the data on iron of Nobel Prize winner, P. W. Bridgman. This discovery forcefully called the capabilities of the shock-compression technique to the static high-pressure scientific community.

Robert Graham and James Asay conceived the symbol, and the mechanical design of the symbol for the explosive fixture was done by Mark Anderson, all of Sandia National Laboratories.

\section{APPENDIX A REFERENCE}

A1. This write-up was part of the Aug. 15, 1989 minutes from the topical groups business meeting in Albuquerque, N.M 